\title{
PENINGKATAN HASIL BELAJAR SISWA PADA MATA PELAJARAN PKN MELALUI PEMBELAJARAN KOOPERATIF TIPE ROLE PLAYING DI KELAS VI SDN IV KOTA PAREPARE
}

\author{
Ritha Tuken \\ UPP PGSD Parepare Fakultas Ilmu Pendidikan UNM \\ ritha.tuken@unm.ac.id
}

\begin{abstract}
ABSTRAK
Permasalahan dalam penelitian ini adalah: 1) Bagaimanakah proses pelaksanaan pembelajaran dengan menggunakan model pembelajaran role playing pada mata pelajaran PKn di kelas VI SDN IV Kota Parepare Kabupaten Enrekang?. Dari rumusan masalah tersebut, maka penelitian bertujuan: 1) Untuk mengetahui informasi tentang proses pelaksanaan pembelajaran dengan menggunakan model role playing dalam meningkatkan hasil belajar PKn di kelas VI SDN IV Kota Parepare Kabupaten Enrekang. Pendekatan penelitian adalah pendekatan kualitatif dengan jenis penelitian adalah penelitian tindakan kelas. Penelitian ini fokus pada proses aktivitas siswa dan guru dengan menerapkan pembelajaran kooperatif tipe role playing dan fokus hasil belajar siswa setelah pelaksanaan pembelajaran dengan menggunakan model pembelajaran kooperatif tipe role playing. Penelitian dilaksanakan di SDN IV Kota Parepare dengan subjek adalah guru dan siswa kelas VI SDN IV Kota Parepare yang berjumlah 30 orang, yang terdiri dari 16 laki-laki dan 14 perempuan. Prosedur dan desain penelitian yang digunakan yakni: perencanaan, pelaksanaan tindakan, observasi dan refleksi. Dari pelaksanaan diperoleh data yang dikumpulkan dengan teknik observasi, tes hasil belajar dan dokumentasi. Selanjutnya data tersebut dianalisis dan diolah secara kualitatif. Hasil belajar yang diperoleh dari taraf keberhasilan siswa yang tuntas mencapai KKM sekolah, yang cenderung mengalami peningkatan, berturut-turut: siklus I, kualifikasi cukup, dan siklus II, kualifikasi baik. Kesimpulan hasil penelitian yaitu terjadi peningkatan hasil belajar siswa pada mata pelajaran PKn melalui pembelajaran kooperatif tipe role playing di kelas VI SDN IV Kota Parepare
\end{abstract}

Kata Kunci: hasil belajar, metode role playing

\section{PENDAHULUAN}

Sebagai usaha memanusiakan manusia, pendidikan sedapat mungkin diusahakan mengoptimalkan pengembangan potensi kemanusiaan siswa melalui kegiatan belajar mengajar atau dengan cara lain yang dikenal dan diakui masyarakat. Undang-undang dasar 1945 Pasal 31 ayat (1) menyebutkan bahwa tiap-tiap warga Negara berhak mendapatkan pengajaran. Oleh karena itu, pemerintah sebagai penyelenggara Negara mengusahakan dan menyelenggarakan pendidikan nasional yang diatur dengan undang-undang. Pemerintah menyelenggarakan pendidikan bagi warganya dengan berdasarkan pada suatu sistem pendidikan nasional sebagaimana tercantum dalam undang-undang nomor 20 tahun 2003 tentang sistem pendidikan nasional yang menyatakan bahwa:

Pendidikan nasional berfungsi

mengembangkan kemampuan dan

membentuk watak serta peradaban

bangsa yang bermartabat dalam rangka mencerdaskan kehidupan bangsa, bertujuan untuk berkembangnya potensi Siswa, agar menjadi manusia yang beriman dan bertakwa kepada Tuhan Yang Maha Esa, berakhlak mulia, sehat, berilmu, cakap, kreatif, mandiri, dan menjadi warga Negara yang demokratis serta bertanggung jawab.

Salah satu upaya untuk mewujudkan tujuan pendidikan nasional adalah dengan pelaksanaan proses pendidikan di sekolah dasar yang terdiri dari beberapa mata pelajaran, salah satunya adalah mata pelajaran Pendidikan Kewarganegaraan (PKn). Mata pelajaran Pendidikan Kewarganegaran (PKn) di Sekolah Dasar (SD) berdasarkann Kurikulum Tingkat Satuan Pendidikan (KTSP 2006) merupakan mata pelajaran yang memfokuskan pada pembentukan warga negara yang memahami dan mampu melaksanakan hak-hak dan kewajibannya untuk menjadi warganegara Indonesia yang 
cerdas, terampil, dan berkarakter yang diamanatkan oleh pancasila UUD 1945. Salah satu tujuan pelaksanaan proses pendidikan khususnya pada mata pelajaran Pendidikan Kewarganegaraan (PKn) pada dasarnya adalah untuk membantu mengembangkan pendidikan pembelajaran dalam meningkatkan moral siswa di sekolah.

Proses pendidikan di sekolah dasar merupakan landasan paling mendasar untuk terselenggaranya kegiatan belajar mengajar pada jenjang yang lebih tinggi yaitu pendidikan menengah dan jenjang pendidikan perguruan tinggi. Ini berarti berhasil tidaknya pencapaian tujuan pendidikan banyak tergantung kepada bagaimana proses belajar yang dialami siswa pada jenjang pendidikan sekolah dasar. Untuk menciptakan proses pembelajaran yang efektif, proses pembelajaran termasuk materi ajar harus memiliki panduan yang sistematis sesuai tingkatan siswa. Kurikulum merupakan acuan dalam pembelajaran yang berjenjang agar efektif dan efesien.

Kurikulum pendidikan yang dibuat berjenjang dan sistematis, mencantumkan mata pelajaran diantaranya adalah mata pelajaran Pendidikan Kewarganegaraan (PKn). Melalui $\mathrm{PKn}$, siswa dapat mengetahui budaya bangsa, selain itu siswa dapat mengetahui hak-hak dan kewajibannya untuk menjadi warga negara yang baik. PKn dapat menjadi sarana pengajaran kepada siswa tentang kewajiban warga Negara, diantaranya ikut serta membela dan mempertahankan keutuhan Negara. Hal ini dipertegas dalam Undang-Undang Republik Indonesia Nomor 3 tahun 2002 tentang Bela Negara, pada pasal 9 ayat 2 disebutkan bahwa:

" Keikutsertaan warga Negara dalam upaya bela Negara, sebagaimana dimaksud dalam ayat (1), diselenggarakan melalui, salah satunya adalah Pendidikan Kewarganegaraan (PKn)".

Mata pelajaran PKn pada dasarnya adalah untuk membantu mengembangkan pendidikan pembelajaran dalam meningkatkan moral siswa di sekolah. Menurut Dihardja (2000: 1-2) bahwa:

Pembelajaran di SD adalah tahapan pembelajaran penting bagi seorang anak yang sedang dalam masa pertumbuhan dan perkembangan serta masa-masa peka sebagai tempat penanaman nilai dan moral, mengingat pentingnya tahapan tersebut maka didedikasi, keahlian dan keterampilan mengajar para guru SD harus lebih profesional lebih bervariasi dan berkualitas.

Salah satu kajian yang tercantum dalam Kurikulum Tingkat Satuan Pendidikan (KTSP 2006) dalam pembelajaran Pendidikan Kewarganegaraann (PKn) yang terdapat di sekolah dasar kelas VI, dapat diwujudkan dengan penelahaan konsep PKn yang benar, baik dalam bentuk sikap dan konsep-konsep yang benar dapat berimplikasi pada pembelajaran. Karena mata pelajaran $\mathrm{PKn}$ masih sangat luas dan memerlukan banyak pengembangan konsep, sehingga untuk mencapai hasil belajar yang baik dan efektif maka sudah tidak diragukan lagi insan pendidik harus memahami dan menerapkan model-model pembelajaran yang benar dan sesuai dengan materi yang dipelajari.

Terkait mata pelajaran pendidikan kewarganegaraan, diatur dalam peraturan menteri pendidikan nasional nomor 22 tahun 2006, tentang standar isi untuk satuan pendidikan dasar dan menengah, menjelaskan bahwa: Kelompok mata pembelajaran kewarganegaraan dan kepribadian dimaksudkan untuk meningkatkan kesadaran dan wawasan peserta didik akan status, hak, kewajiban dalam kehidupan bermasyarakat, berbangsa dan bernegara, serta peningkatan kualitas dirinya sebagai manusia.

Pada dasarnya mata pelajaran PKn merupakan pelajaran yang menyenangkan jika disajikan dengan metode yang tepat. Mengingat PKn adalah Mata pelajaran yang menekankan pada pengembangan nilai, moral, dan etika maka dalam pembelajaran perlu diterapkan model role playing. Model ini mengarahkan siswa untuk mengkreasi peristiwa sejarah atau kejadian yang akan muncul pada era globalisasi. Berdasarkan hal tersebut, maka peneliti mengangkat penerapan model pembelajaran role playing sebagai solusi konkret untuk meningkat hasil belajar PKn pada siswa kelas VI SDN IV Kota Parepare. Untuk mendapatkan fakta yang melandasi perlunya pelaksanaan penelitian, peneliti mengadakan kegiatan pra penelitian pada tanggal 08 September 2012 di SDN IV Kota Parepare. Kegiatan pra penelitian tersebut yaitu mengumpulkan data keadaan awal melalui observasi awal terhadap siswa kelas VI di sekolah tersebut. Dari observasi awal 
pembelajaran PKn yang dilaksanakan di kelas, peneliti memperoleh informasi sebagai berikut: 1) guru dalam mengajarkan konsep pada mata pelajaran PKn pada siswa kurang melibatkan siswa secara aktif dalam interaksi belajar mengajar atau dalam hal ini guru yang lebih aktif dalam pembelajaran, 2) guru dalam mengajar kurang menggunakan model pembelajaran yang inovatif.

Dari hasil observasi peneliti terungkap juga bahwa faktor dari siswa: (1) hasil belajar siswa rendah, disebabkan minat belajar siswa kurang, terlihat pada saat guru menjelaskan materi pembelajaran sebagian siswa hanya bermain, 2) siswa kurang aktif dalam pembelajaran. Ini terlihat ketika peneliti mengadakan observasi di SD tersebut, sehingga peneliti menarik kesimpulan bahwa kesalahan penggunaan metode adalah salah satu faktor turunnya perhatian dan minat siswa yang berdampak pada hasil belajar.

Sejalan dengan kesimpulan peneliti, Sukardjo dan Ukim Komaruddin (2009) mengemukakan bahwa ada beberapa faktor yang ikut mempengaruhi hasil belajar siswa antara lain: (1) faktor guru, (2) materi dan media pembelajaran, (3) tujuan pelajaran, (4) metode mengajar, (5) instrument.

Dari pendapat tersebut dikatakan salah satu faktor menurunnya hasil belajar siswa dikarenakan oleh penggunaan metode mengajar yang tidak tepat, Menurut peneliti, dengan menggunakan pembelajaran kooperatif tipe role playing maka siswa dapat lebih mudah memahami suatu konsep karena siswa melakukan sendiri dibanding siswa hanya duduk diam dan mendengarkan saja penjelasan guru, olehnya peneliti menggunakan model ini untuk melakukannya pada penelitian tindakan kelas.

Berdasarkan permasalahan yang diidentifikasi pada proses belajar mengajar mata pelajaran PKn pada murid kelas VI SDN IV Kota Parepare tersebut, maka salah satu pemecahan masalah yang dapat dilakukan oleh peneliti adalah dengan merubah pembelajaran yang digunakan kearah pembelajaran yang dapat memberikan peluang kepada murid untuk terlibat secara aktif dalam proses belajar mengajar. Pembelajaran yang dimaksud adalah pembelajaran kooperatif tipe role playing. Hal ini sesuai dengan pendapat Puswitasari (2008:1) yaitu:
Pembelajaran Kooperatif tipe role playing dapat meningkatkan aktivitas, antusiasme, dan hasil belajar siswa. Peningkatan aktivitas, antusiasme dan hasil belajar siswa tersebut dicapai dengan mengoptimalkan perangkat pembelajaran dalam role playing itu sendiri.

Berdasarkan pendapat tersebut, dapat dipahami bahwa dengan menggunakan pembelajaran kooperatif tipe role playing dan mengoptimalkan perangkat dalam role playing itu sendiri maka, siswa akan lebih aktif dan antusias dalam mengikuti proses belajar mengajar sehingga pada akhirnya hasil belajar siswa akan lebih meningkat. Oleh karena itu, peneliti bermaksud untuk mengadakan suatu Penelitian Tindakan Kelas (PTK) nantinya dengan judul "Peningkatan Hasil Belajar Siswa pada Mata Pelajaran Pendidikan Kewarganegaraan (PKn) Melalui Pembelajaran Kooperatif Tipe Role Playing di Kelas VI SDN IV Kota Parepare

\section{METODE PENELITIAN}

Pendekatan yang digunakan dalam penelitian ini adalah pendekatan kualitatif, yaitu pendekatan penelitian untuk mendeskripsikan aktifitas siswa dan guru dalam pelaksanaan tindakan pembelajaran. Jenis penelitian ini adalah penelitian tindakan kelas (classroom action research) atau yang biasa juga disebut PTK dengan tahapantahapan pelaksanaan meliputi: perencanaan, pelaksanaan tindakan, obsrvasi, dan refleksi secara berulang. Penelitian tindakan kelas ini dilaksanakan selama dua siklus dengan penerapan model pembelajaran kooperatif tipe Role Playing, ketika permasalahan belum terselesaikan dalam satu siklus tersebut, maka dapat dilanjut ke siklus berikutnya.

Penelitian yang dilaksanakan difokuskan pada dua aspek pengamatan utama, yaitu fokus pada proses/kegiatan pembelajaran dan fokus pada evaluasi hasil penggunaan model pembelajaran tipe Role Playing.

1.

Fokus proses dalam penelitian ini yaitu memfokuskan pada langkah-langkah penggunaan model pembelajaran kooperatif tipe role playing dan mengamati siswa dalam proses belajar mengajar serta guru dalam menerapkan pembelajaran kooperatif tipe Role Playing yang digunakan. 
2.

Fokus hasil dalam penelitian ini adalah memfokuskan pada peningkatan hasil belajar siswa pada mata pelajaran Pendidikan Kewarganegaraan (PKn).

Penelitian tindakan kelas ini dilaksanakan di SDN IV Kota Parepare, peneliti memilih lokasi ini karena ada beberapa faktor, diantaranya: 1) guru di sekolah tersebut belum pernah menerapkan model pembelajaran kooperatif tipe role playing 2 ) peneliti adalah salah satu alumni dari sekolah tersebut. 3) di samping itu hubungan peneliti dan para guru-guru di sekitar sekolah sangat harmonis, sehingga akan memudahkan komunikasi dalam pelaksanaan. Adapun yang menjadi subjek dalam penelitian ini adalah siswa dan guru kelas VI SDN IV Kota Parepare yang jumlah siswanya sebanyak 30 orang, dengan rincian jumlah siswa lakilaki 16 orang dan siswa perempuan sebanyak 14 orang.

Pelaksanaan penelitian ini dilakukan dalam dua siklus, dalam satu siklus diadakan dua kali pertemuan. Pelaksanaan penelitian dilakukan karena adanya permasalahan yang dialami dalam proses pembelajaran, kemudian dilakukan perencanaan tindakan untuk mengatasi permasalahan tersebut, yang dilanjutkan dengan upaya pelaksanaan tindakan dan observasi dan refleksi.

Untuk mengumpulkan data dalam penelitian ini dilakukan dengan, pengamatan (Observasi), dokumentasi dan tes. Beberapa tekhnik tersebut diuraikan sebagai berikut:

1. Pengamatan (Observasi)

Merupakan kegiatan pengumpulan data pengamatan terhadap proses pembelajaran. Data pengamatan tersebut dicatat dalam lembar observasi aktifitas guru dan lembar observasi aktifitas siswa, sehingga kedua lembar observasi tersebut menjadi alat/instrument observasi.

2. Tes

Merupakan kegiatan pengumpulan data hasil belajar PKn melalui tes hasil belajar PKn sehingga dapat diketahui peningkatan hasil belajar PKn siswa. Instrument tes yang digunakan adalah soal tes, rambu-rambu jawaban, dan pekerjaan siswa.

\section{Dokumentasi}

Dokumentasi merupakan kegiatan atau proses pekerjaan mencatat atau merekam suastu peristiwa dan objek (aktivitas) yang dianggap penting dan berharga serta perolehan data-data awal siswa dan guru kelas,dengan tujuan untuk memberikan gambaran yang lebih jelas tentang situasi yang dilakukan dalam proses pembelajaran berupa arsip-arsip hasil belajar yang dapat memberi informasi data keberhasilan siswa dan dokumen berupa fotofoto yang menggambarkan situasi pembelajaran, sebagai pelengkap penelitian yang disesuaikan dengan langkah-langkah pembelajaran kooperatif tipe role playing.

Analisis data dilakukan dengan cara mengelompokkan data aspek guru dan aspek siswa. Tehnik yang digunakan adalah tehnik analisis data kualitatif yang dikembangkan oleh Miles dan Huberman (Moleong, 2001). yang terdiri dari 3 tahap kegiatan yaitu: (1) Mereduksi data, (2) Menyajikan data, (3) menarik kesimpulan dan verifikasi.

1) Mereduksi data adalah proses kegiatan menyeleksi, memfokuskan dan menyederhanakan semua data yang diperoleh mulai dari awal pengumpulan data sampai penyusunan laporan penelitian.

2) Menyajikan data adalah kegiatan mengorganisasikan hasil reduksi dengan cara menyusun secara naratif sekumpulan informasi yang telah diperoleh dari hasil memberikan kemungkinan penarikan kesimpulan dan pengambilan tindakan.

3) Menarik kesimpulan dan verifikasi data adalah memberikan kesimpulan terhadap hasil penafsiran data evaluasi yang mencakup pencarian makna data serta memberikan penjelasan selanjutnya dilakukan kegiatan verifikasi yaitu menguji kebenaran, kekokohan makna-makna yang muncul dari data.

\section{HASIL \& PEMBAHASAN}

Hasil penelitian yang terdiri atas aktivitas siswa dan guru dalam pembelajaran PKn dengan menerapkan model pembelajaran role playing mengalami peningkatan yang signifikan. Hal ini terbukti dari hasil observasi dalam pembelajaran dan hasil tes formatif siswa yang dilkukan pada akhir pembelajaran. Peningkatan hasil belajar siswa terlaksana karena adanya kerjasama antara peneliti dan guru kelas yang secara kolaboratif menyusun Rencana Pelaksanaan Pembelajaran yang dilakukan secara berulang-ulang. Disetiap pelaksanaan siklus tedapat adanya kekurangankekurangan yang terjadi didalamnya, namun hal tersebut segera diperbaiki demi 
peningkatan hasil pembelajaran yang diinginkan.

Pada siklus I, proses pembelajaran yang dilakukan oleh guru dikualisifikasikan kurang (K). Tujuan pembelajaran yang dirancang oleh peneliti yang berkolaborasi dengan guru kelas adalah (1) siswa mampu menjelaskan pengertian pemilu (2) siswa mampu menyebutkan asas-asas pemilu (3) siswa mampu mempraktekkan cara memilih secara sederhana. Pelaksanaan pembelajaran ini diawali dengan persiapan alat dan bahan yang digunakan peneliti dalam pembelajaran.

Didalam pelaksanaan pembelajaran masih terdapat berbagai kekurang-kekuangan yang dilakukan oleh guru. Namun hal tersebut segera diperbaiki oleh guru untuk peningkatan hasil belajar yang diinginkan.

Pada siklus I proses bermain peran belum berjalan dengan sempurna, hal ini dikarenakan ternyata siswa masih belum terbiasa dengan model belajar semacam ini karena selama ini metode yang biasa di pakai oleh guru kelasnya adalah ceramah dan diskusi. Peneliti tak menyadari hal ini, sehingga tidak terlalu rinci dalam menjelaskan dasar-dasar permainan peran. Selain itu, peneliti juga terlambat menyadari bahwa gambaran awal tentang materi pemillihan umum sangat urgen dalam membantu siswa mendalami perannya dalam pokok bahasan pemilihan umum. Akibatnya, terlihat pemahaman siswa terhadap materi pemilu dan pilkada dengan pokok bahasan pemilihan umum masih sangat rendah.

Hal ini dapat dilihat dari hasil tes evaluasi siswa.Pada tindakan siklus I, menunjukan nilai rata-rata kelas $66,67 \%$ dengan 1 orang siswa memperoleh kualifikasi sangat baik, 17 orang memperoleh kualifikasi baik, 6 orang berada pada

kualifikasi cukup dan 4 orang berada pada kualifikasi kurang dan 2 orang berada pada kualifikasi sangat kurang . Untuk lebih jelasnya akan ditampilkan pada tabel berikut ini.

Tabel 4.1 Penguasaan Siswa Terhadap Materi Siklus I

\begin{tabular}{lccc}
\hline Kualifikasi & Nilai & Frekuensi & Persentase \\
Sangat Baik & $85-100$ & 1 & $3 \%$ \\
\hline Baik & $70-84$ & 17 & $57 \%$ \\
\hline Cukup & $55-69$ & 6 & $20 \%$ \\
\hline Kurang & $46-54$ & 4 & $13 \%$ \\
\hline Sangat Kurang & $0-45$ & 2 & $7 \%$ \\
\hline Jumlah & & $\mathbf{3 0}$ & $\mathbf{1 0 0 \%}$ \\
\hline
\end{tabular}

Pada siklus II proses bermain peran pada pembelajaran role playing telah berjalan dengan sangat baik, hal ini dikarenakan siswa telah terbiasa sebelumnya dengan model belajar bermain peran pada siklus I. Selain itu, siswa terlihat lebih rileks dalam menjalankan skenario bermain peran. Sehingga makna yang ingin disampaikan kepada masing-masing kelompok pengamat dapat dengan efektif tersampaikan.

Sehingga terlihat pemahaman siswa terhadap materi pemilu dan pilkada dengan pokok bahasan pemilihan kepala daerah dan wakil kepala daerah mengalami peningkatan yang signifikan. Hal ini dapat dilihat dari hasil tes evaluasi siswa berikut:

Tabel 4.2 Rekapitulasi Hasil Tes Siklus II

\begin{tabular}{lccc}
\hline \multicolumn{1}{c}{ Kualifikasi } & Nilai & Frekuensi & Persentase \\
\hline Sangat Baik & $85-100$ & 3 & $10 \%$ \\
\hline Baik & $70-84$ & 20 & $67 \%$ \\
\hline Cukup & $55-69$ & 4 & $13 \%$ \\
\hline Kurang & $46-54$ & 3 & $10 \%$ \\
\hline Sangat Kurang & $0-45$ & - & $-\%$ \\
\hline Jumlah & & $\mathbf{2 0}$ & $\mathbf{1 0 0 \%}$ \\
\hline
\end{tabular}

Dari tabel diatas dapat dilihat bahwa diantara 30 siswa, terdapat 23 orang atau $77 \%$ siswa yang tuntas mencapai KKM (memperoleh nilai $70 \mathrm{ke}$ atas), sementara 7 orang atau $23 \%$ lainnya belum tuntas memenui KKM (nilai perolehan di bawa 70). Taraf keberhasilan $77 \%$ berada pada rentang $70 \%$ $84 \%$ tabel keberhasilan dengan kulifikasi baik. 


\begin{tabular}{lccc}
\hline Kurang & $46-54$ & 3 & $10 \%$ \\
\hline Sangat Kurang & $0-45$ & - & $-\%$ \\
\hline Jumlah & & $\mathbf{2 0}$ & $\mathbf{1 0 0 \%}$ \\
\hline
\end{tabular}

Dari tabel diatas dapat dilihat bahwa diantara 30 siswa, terdapat 23 orang atau $77 \%$ siswa yang tuntas mencapai KKM (memperoleh nilai $70 \mathrm{ke}$ atas), sementara 7 orang atau $23 \%$ lainnya belum tuntas memenui KKM (nilai perolehan di bawa 70). Taraf keberhasilan $77 \%$ berada pada rentang $70 \%$ $84 \%$ tabel keberhasilan dengan kulifikasi baik.

Karena itu, pelaksanaan pembelajaran pada siklus II menunjukkan keberhasilan yang signifikan di banding siklus I yang dilaksanakan sebelumnya. Perbaikanperbaikan atas kekurangan yang terdapat pada siklus sebelumnya menyebabkan adanya peningkatan tersebut.

Adapun kriteria yang digunakan untuk mengungkapkan kemampuan siswa adalah sesuai dengan kriteria standar yang diungkapkan oleh Mills, (2000: 9). Berdasarkan kriteria standar tersebut, maka peneliti menentukan tingkat kriteria keberhasilan tindakan pada penelitian ini dilihat dari aktivitas dan hasil belajar siswa secara individu maupun klasikal pada setiap siklus telah meningkat dan menunjukkan tingkat pencapaian ketuntasan $\geq 70 \%$. Dari grafik di atas kita dapat menarik kesimpulan bahwa penerapan pembelajaran role playing dapat meningkatkan hasil belajar PKn pada siswa kelas VI SDN IV Kota Parepare. Dengan melihat indikator keberhasilan yang ditetapkan maka penelitian ini telah berhasil, sehingga pada penelitian di siklus II ini dihentikan karena menggangap hasil pencapaian telah berhasil. Dengan begitu hipotesis yang dibangun oleh peneliti yakni jika model pembelajaran role playing diterapakan dengan tepat, maka akan meningkatkan hasil belajar PKn pada siswa kelas VI SDN IV Kota Parepare

Keberhasilan siklus kedua mencapai kualifikasi Baik karena, pada kegiatan pembelajaran yang terakhir siswa mampu melaksanakan semua indikator-indikator yang direncanakan oleh peneliti. Hal ini menunjukkan bahwa siswa telah menerapkan langkah-langkah model pembelajaran role playing dalam pembelajaran. Keberhasilan tindakan dari siklus pertama ke siklus kedua karena siswa telah memahami indikator pembelajaran dengan model pembelajaran role playing.

\section{KESIMPULAN \& SARAN}

Berdasarkan deskripsi data dan

pembahasan hasil penelitian yang telah dipaparkan sebelumnya, maka dapat disimpulkan oleh peneliti bahwa penerapan model pembelajaran role playing dapat meningkatkan hasil belajar siswa pada mata pelajaran PKn di kelas VI SDN IV Kota Parepare. Kesimpulan ini ditarik setelah menelaah hasil penelitian yang dilakukan setelah melalui tahap pra-penelitian sampai siklus II yang masing-masing dilakukan bertahap dan teratur.

Bagi guru yang tertarik untuk menerapkan model pembelajaran role playing dalam pembelajaran Pendidikan kewarganegaraan, disarankan memperhatikan hal-hal sebagai berikut:

a. Hendaknya menciptakan suasana belajar yang menyenangkan sehingga siswa memiliki motivasi dalam belajar.

b. Perlu pengelolaan waktu secara maksimal mengalokasikan waktu secara baik, karena kegiatan yang terdapat dalam model pembelajaran role playing biasanya

Fluktuatif.

c. Harus terfokus pada pesan atau makna yang ingin disampaikan, sehingga yang urgen dilihat bukan pada skenario atau dialog yang harus persis, tetapi pada ketepatan pemahaman siswa akan apa yang diperankan.

d. Harus membimbing siswa yang mengalami kesulitan.

Bagi peneliti yang berminat, diharapkan untuk mengembangkan model pembelajaran role playing pada materi lain yang terdapat dalam pembelajaran di Sekolah Dasar. 
Depdiknas. 2006. Kurikulum Tingkat satuan pendidikan mata pelajaran PKn. Jakarta: Departemen Pendidikan Nasional

Depdikbud. 2006. Kurikulum Tingkat Satuan Pendidikan. Jakarta: Departemen Pendidikan Kebudayaan

Dihardja, Djaja. 2000. Pendidikan Pancasila dan Kewarganegaraan. Jakarta: Depdiknas

Dimyanti, Mudjiono. 2002. Belajar dan pembelajaran. Jakarta: Direktorat Jenderal Perguruan Tinggi Depdikbud.

Hanafiah \& Suhana . 2009 . Konsep Strategi Pembelajaran. Bandung : Refika Aditama.

Imron, Syaiful. 2009. Role Playing. http://gooogle/ipank_say.blogspot.com, diakses tanggal 23 September 2012.

Khalik, Abdul. 2008. Penelitian Tindakan Kelas. UPP PGSD Parepare.

Makhrufi. 2009. Role Playing : Suatu Alternatif Pembelajaran yang Efektif dan Menyenagkan dalam Meningkatkan Keterampilan Murid. http://www.infodiknas.com, (diakses tanggal 23 September 2012).

Samira. 2008. Peranan Pembelajaran PKn dalam Meningkatkan Moral Siswa di Sekolah Dasar. Makassar : Universitas Negeri Makassars

Sardiman. 2006. Interaksi dan Motivasi Belajar Mengajar. Jakarta: PT. Raja Grasindo.

Sinring, Abdullah, dkk. 2012. Pedoman penulisan skripsi program S-1 Fakultas Ilmu Pendidikan UNM. Makassar: FIP UNM.

Sisdiknas. 2006. Himpunan Peraturan Perundang-Undangan UU NO. 20 Tahun 2003. Jakarta: Fokusmedia.

Slameto. 2003. Belajar Dan Faktor Yang Mempengaruhinya. Jakarta: Rineka Cipta.

Sudjana. Nana. 2000. Cara Belajar Mueid Aktif Dalam Proses Belajar Mengajar. Bandung: Sinar Baru.

Sukardjo dan Ukim. 2009. Landasan Pendidikan. Jakarta: Rajawali Press.

Suryabrata, Sumadi. 2004. Psikologi Pendidikan. Jakarta: PT Raja Grafindo Persada.

Syamsu. 2000. Role Playing. http://www.infodiknas.com, diakses tanggal 23 September 2012.
Undang-Undang RI Nomor 20 Tahun 2003 Tentang Sistem Pendidikan Nasional. Surabaya: Terbit Terang.

Wahab, Abdul Aziz. 2007. Metode dan ModelModel Mengajar Ilmu Pengetahuan Sosial (IPS). Bandung: Alfabeta. 